\title{
On the Variability of Southern Ocean Front Locations Between Southern Brazil and the Antarctic Peninsula
}

\author{
YOSHIMINE IKEDA \\ Instıtuto Oceanografico, Universidade de Sāo Paulo, Brazil
}

Gerold Siedler ANd Marek Zwierz

Institut für Meereskunde, Kiel, Federal Republic of Germany

\begin{abstract}
A 4-year expendable bathythermograph data set (1984-1987) from the area between southern Brazil and the Antarctic Peninsula provides information on the interannual variability of front locations. Two boundaries of subtropical water at different depths are identified north and south of the Brazil CurrentFalkland (Malvinas) Current confluence zone. The northern Subtropical Front is displaced over a large part of the Argentine Basin from one observational period to the other. The shallow southern Subtropical Front appears fixed to the Falkland Escarpment. The Polar Front and Subantarctic Front locations do not vary much, except for one case where a cold core eddy in the Polar Frontal Zone causes a large northward displacement of the Subantarctic Front.
\end{abstract}

\section{INTRODUCTION}

The Southern Ocean contains several thermohaline fronts. Among them the Antarctic Polar Front (Antarctic Convergence) and the Subtropical Front (Subtropical Convergence) have long been recognized [Brennecke, 1921; Meinardus, 1923; Deacon, 1937; Schott, 1943]. More recent observations with mesoscale resolution, particularly from field experiments during the International Southern Ocean Studies program, indicate that narrow current bands with $\sim 50-\mathrm{km}$ horizontal extension are related to the fronts in the Drake Passage [Baker et al., 1977; Nowlin et al., 1977; Nowlin and Clifford, 1982]. It has also been demonstrated that there are large space-time variations in the frontal locations and that the related meandering currents shed vortices into the neighboring zones [Mackintosh, 1946; Joyce and Patterson, 1977; Legeckis, 1977; Gordon et al., 1977, 1978; Peterson et al., 1982] (see also Bryden [1983]). The following fronts and water mass zones have been described [World Climate Research Programme, 1985], from north to south (Figure 1): Subtropical Front (STF), Subantarctic Zone (SAZ), Subantarctic Front (SAF), Polar Frontal Zone (PFZ), Polar Front (PF), and Antarctic Zone (AAZ). The region to the east of Drake Passage is of particular interest. The northern part of the Antarctic Circumpolar Current, after leaving the Drake Passage, turns northward to flow as the Falkland (Malvinas) Current [Deacon, 1937], which meets the southward flowing Brazil Current. Strong eddy activity is found in this confluence zone [Legeckis and Gordon, 1982; Gordon and Greengrove, 1986; Roden, 1986].

To study the spatial and interannual variability of upper ocean temperature in the southwestern Atlantic, expendable bathythermograph (XBT) sections from four summer seasons are used here. These sections extend from southern Brazil to the Antarctic Peninsula, approximately along the heavy line shown in Figure 1. After describing the data set, changes in front locations are analyzed.

Copyright 1989 by the American Geophysical Union.

Paper number 88JC03505. 0148-0227/89/88JC-03505\$05.00

\section{The Data Set}

The observations were performed by the Instituto Oceanográfico da Universidade de São Paulo on R/V Professor $W$. Besnard during four summer seasons. The positions of XBT drops are presented in Figure 2, while Table 1 summarizes the cruises and periods. The measurements usually extended through the upper $750 \mathrm{~m}$. Typical spacing of observations was 20 nautical miles $(37 \mathrm{~km})$. Where fronts were expecieci, ine uistanice was reduced to approximately 10 nautical miles $(19 \mathrm{~km})$. Some of the earlier data were presented in sections by $l k e d a$ et al. [1986]. For the present study the data have been further quality controlled, spikes being removed by median filtering and all data points exceeding 750-m depth being deleted.

The four longer-temperature sections and the two sections across the Drake Passage are presented in Figures 3 to 5 . Those sections lie well east of the continental shelf in the Argentine Basin and therefore east of the northward flowing part of the Falkland Current. Earlier authors [Reid et al., 1977; Gordon and Greengrove, 1986] have shown that at their confluence, both the Brazil and Falkland currents separate from the continental margin (Figure 1) and that numerous eddies are found in that region [Legeckis and Gordon, 1982]. Eddy-type variability can also be seen in the northern part of the longer sections, i.e., in the Argentine Basin.

\section{The VARIability OF Front LoCATIONS}

Several regions with large horizontal temperature gradients can be seen in the sections. A complicated pattern exists in the Argentine Basin, the transition zone between the subtropical source water region with predominantly downward heat and salt fluxes and the subpolar source water region with predominantly upward heat and salt fluxes. The thermohaline front on the subtropical water side of this zone was earlier named Brazil Current Front (BCF) and can be traced approximately by the positions of the $10^{\circ} \mathrm{C}$ isotherm and 34.8 isohaline between 300 and $500 \mathrm{~m}$ [Roden, 1986; Gordon and Molinelli, 1982]. In addition, we find another thermal front (haline 


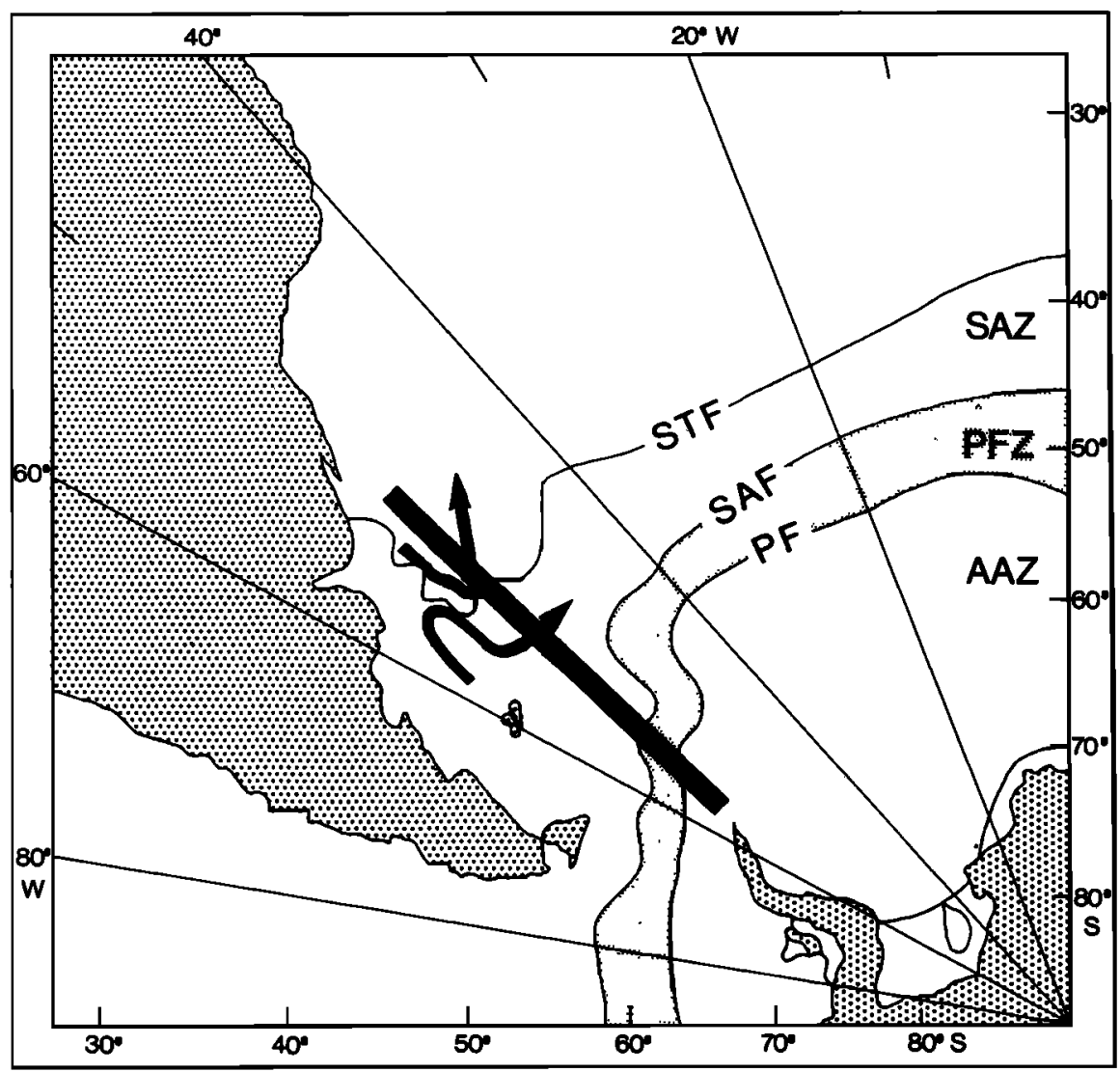

Fig. 1. Surface regimes of the Southern Ocean [after World Climate Research Programme, 1985]. Position of the Subtropical Front is after Deacon [1982]; locations of the Subantarctic and Polar fronts are modified from a figure by Clifford [1983]. The approximate position of the long sections discussed in the present study is given by the heavy line. Bands with arrows indicate schematically the baroclinic flow according to Gordon and Greengrove [1986].

gradient not measured here) in the near-surface water which appears to be confined to the region near the Falkland Escarpment. We therefore call it the Falkland Escarpment Front (FEF). Temperature gradients further south at the Antarctic Polar Front (PF) and the Subantarctic Front (SAF) are less strong, and salinity sections would be important in locating the fronts. Since salinity data were not available here, we follow proposals in earlier investigations for obtaining the positions of these two fronts from temperature alone. The following criteria will be used in locating the four fronts to be discussed here:

1. BCF is the Brazil Current Front, the southern boundary of the warm Brazil Current water: $10^{\circ} \mathrm{C}$ at $300 \mathrm{~m}\left(10^{\circ} \mathrm{C}\right.$ between 300 and $500 \mathrm{~m}$ according to Roden [1986]).

2. FEF is the Falkland Escarpment Front, a surface layer thermal front: $10^{\circ}-12^{\circ} \mathrm{C}$ at $30 \mathrm{~m}$.

3. SAF is the Subantarctic Front: $3^{\circ}-5^{\circ} \mathrm{C}$ at the depth selected for determining PF [Sievers and Emery, 1978].

4. PF is the Polar Front: $1^{\circ}-2^{\circ} \mathrm{C}$ at depth of temperature minimum [Botnikov, 1963], here about $200 \mathrm{~m}$.

High-gradient regions in the temperature range $10^{\circ}-12^{\circ} \mathrm{C}$ between the BCF and FEF are observed and are assumed to be associated with mesoscale eddies or meanders originating

F1g. 2. (opposite) Positions of XBT drops on R/V Professor $W$. Besnard tracks between Southern Brazil and the Antarctic Peninsula and across the Drake Passage. The observations come from summer seasons, the years of which are indicated in the lower left corner. Refer to Table 1 for more details. Bold letters denote end points of vertical sections shown in the following figures.

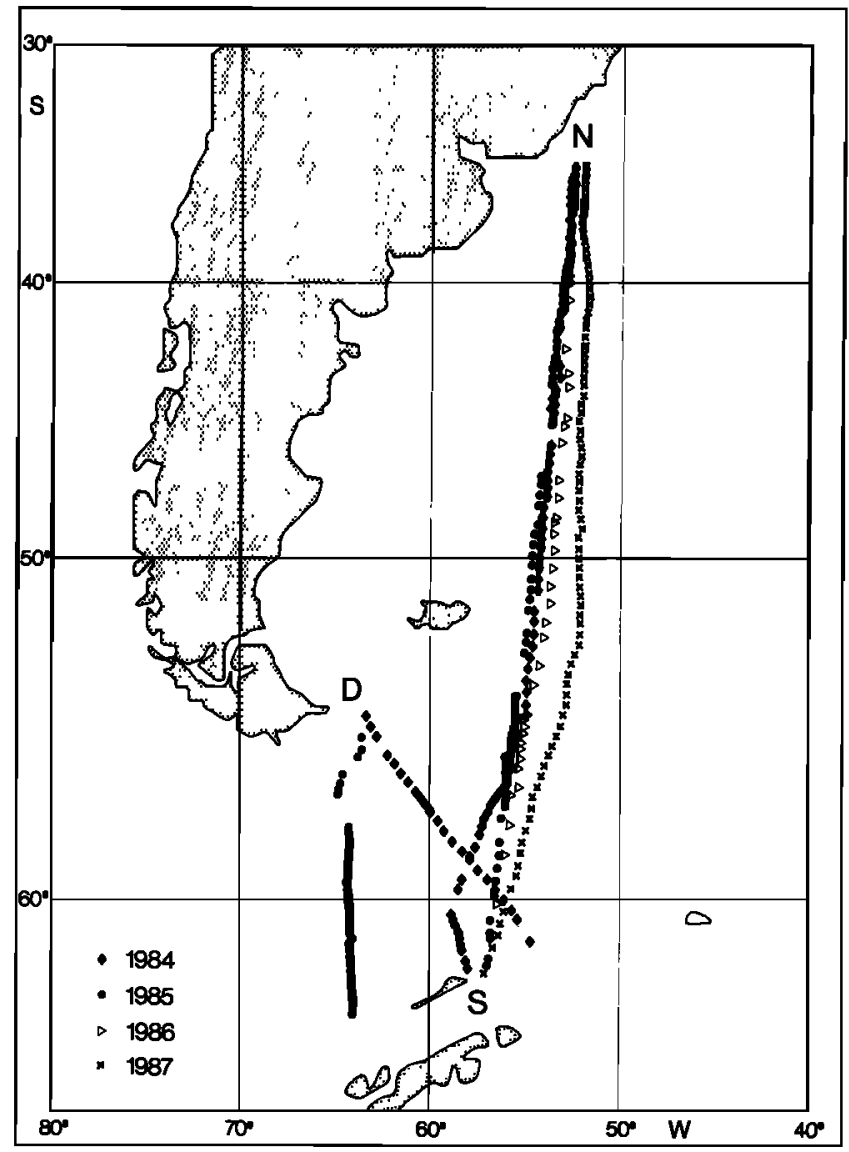


TABLE 1. Summary of Cruises and Observational Periods

\begin{tabular}{ccll}
\hline $\begin{array}{c}\text { Cruise } \\
\text { Proantar }\end{array}$ & $\begin{array}{c}\text { Number of } \\
\text { XBT Drops }\end{array}$ & \multicolumn{1}{c}{ Period } & \multicolumn{1}{c}{ Area } \\
\hline II & 24 & Feb. 2-9, 1984 & Drake Passage \\
II & 79 & Feb. 25-March 3, 1984 & Scotia Sea, Argentine Basin \\
III & 84 & Jan. 12-19, 1985 & Argentine Basin, Scotia Sea \\
III & 46 & Feb. 15-17, 1985 & Drake Passage \\
IV & 40 & Jan. 20-26, 1986 & Argentine Basin, Scotia Sea \\
V & 76 & March 12-20, 1987 & Scotia Sea, Argentine Basin \\
\hline
\end{tabular}

in the confluence region [Legeckis and Gordon, 1982]. The locations of the PF, SAF, FEF, and BCF obtained with the above criteria are indicated by arrows in the sections in Figures 3 to 5 and are summarized in Figure 6 and Table 2. The largest changes are apparent in the position of BCF representing the southwestern edge of the Brazil Current. Since the boundary between the Falkland and Brazil currents is oriented mainly north-south in this region (Figure 1), large northsouth variations in BCF locations along these sections can occur owing to slight east-west shifts of this boundary. The range of meridional displacements in the observations from four years is $\sim 620 \mathrm{~km}$. A much smaller variability occurs at the FEF, where a meridional range of only $\sim 160 \mathrm{~km}$ is observed. This front, representing the southern boundary of a shallow warm layer, is always found above the northern slope of the Falkland Plateau, apparently related to a topographically controlled flow of the Falkland Current in this area. The maximim width of the eddy and meander activity zone between the BCF and FEF is more than $1000 \mathrm{~km}$, much larger than the typical meander amplitudes of $\sim 200 \mathrm{~km}$ given by Legeckis [1977] and Roden [1986]. The Subantarctic and Polar fronts are both observed to migrate over a range of $\sim 160 \mathrm{~km}$. Mackintosh [1946] and Botnikov [1963] found similar or larger ranges.

\section{A Cold Core Eddy in the Polar Frontal Zone}

It is well known from other parts of the ocean that meandering currents frequently shed vortices, either as cold core or as warm core eddies. As mentioned above, earlier observations in the Brazil Current-Falkland Current confluence zone have produced evidence of major eddy production in the area. Also, meandering of both the Subantarctic and Polar fronts is evident in earlier data, and the importance of such fluctuations for poleward heat transport was discussed by Bryden [1979]. However, observations of single eddies have been rather scarce. Joyce et al. [1981] described the development of a cold core cyclonic ring in early 1976 from a Polar Front meander in the Drake Passage, drifting in a northeastward direction through the Polar Frontal Zone after formation. With CTD data available, they were able to estimate its heat and salt content anomalies, the available potential and kinetic energies, and the distribution of potential vorticity. Peterson et al. [1982] analyzed a similar cold core cyclonic ring originating from the Polar Front area in early 1979. At the end of the observational period, the ring had crossed the Polar Frontal Zone and appeared to be pushing through the Subantarctic Front. Again, they were able to determine heat and salt content anomalies. Including the one described by Peterson et al.
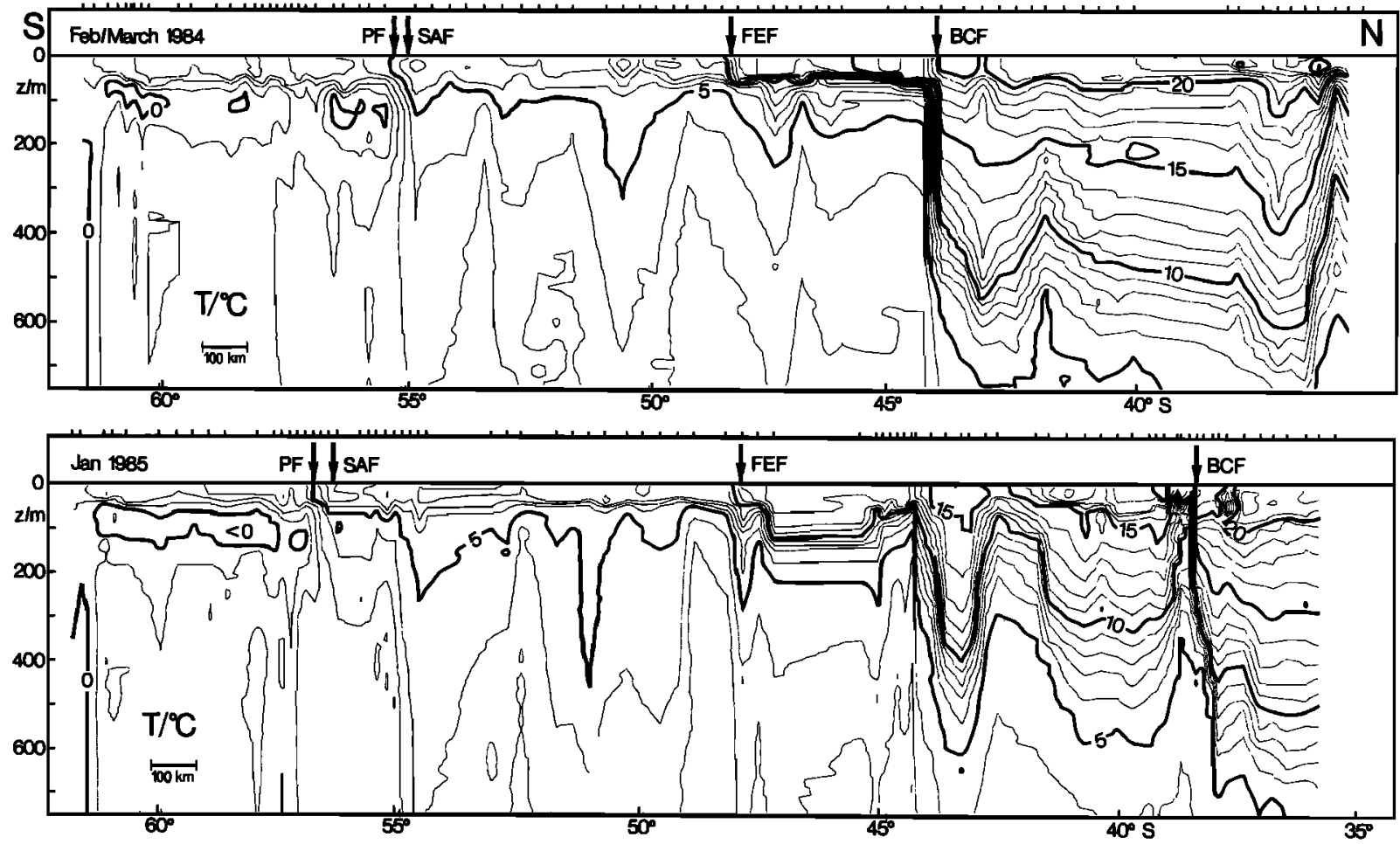

Fig. 3. Temperature section S-N (see Figure 2) from XBT observations in February/March 1984 and January 1985. Tick marks indicate positions of XBT drops. Positions of fronts are given by arrows and front abbreviations. 

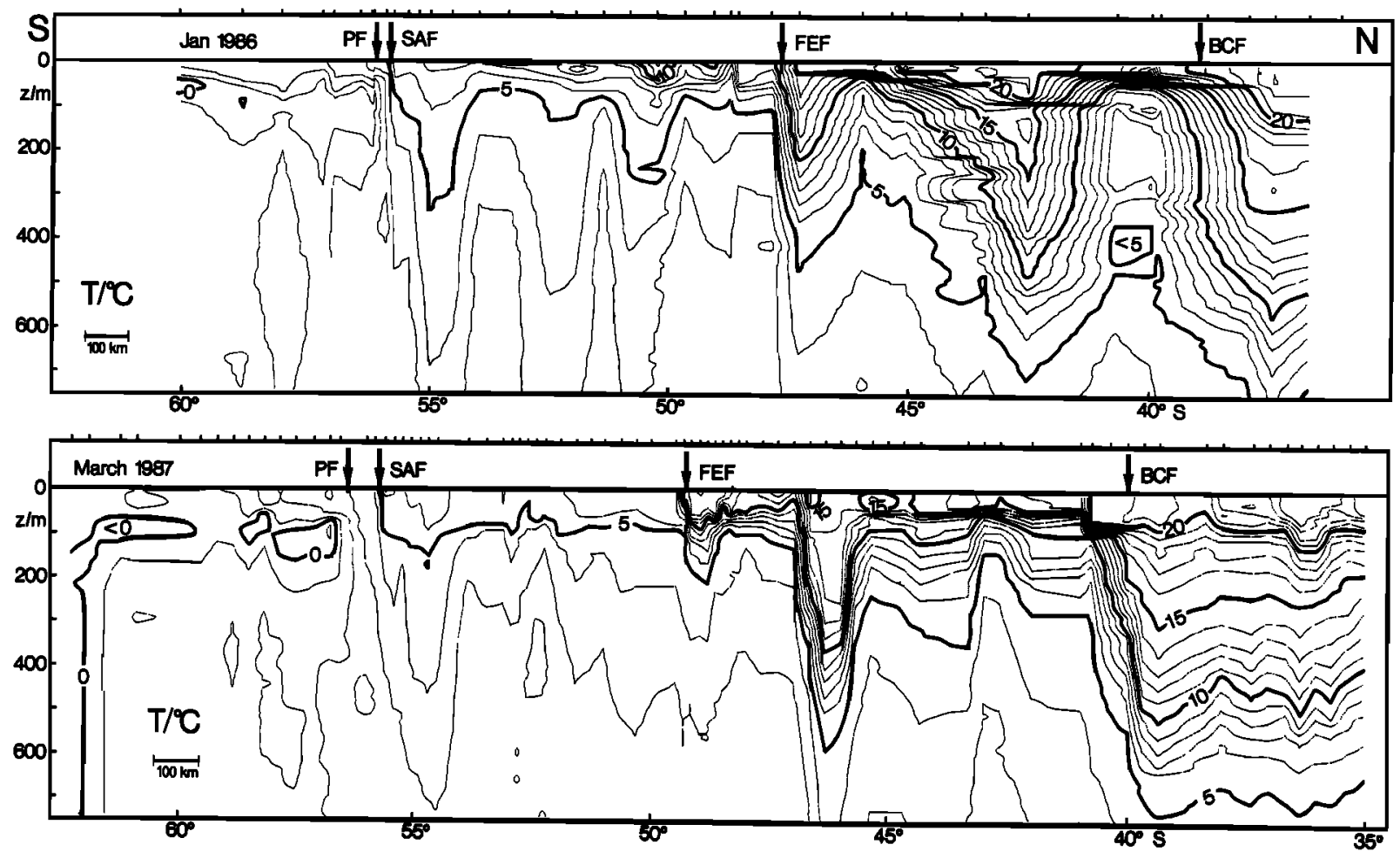

Fig. 4. Temperature section S-N (see Figure 2) from XBT observations in January 1986 and March 1987. Tick marks indicate positions of XBT drops. Positions of fronts are given by arrows and front abbreviations.

[1982], Hofmann and Whitworth [1985] observed three cold core eddies within the Drake Passage in a 1-year period.

A similar cold core eddy in the Polar Frontal Zone is found in our data from the Drake Passage (Figure 5). Selected temperatures inside the cold core are found at deeper levels than farther south, and surface temperatures correspond to those at the northern side of the Polar Front. This is suggestive of a broken-off eddy and not a meander. Since we do not have salinity data from this section, we can only compare the scales with earlier observed eddies. Joyce et al. [1981] gave a typical ring diameter of 60 to $80 \mathrm{~km}$, defined by the $4^{\circ} \mathrm{C}$ isotherm at the surface. The cold core, delineated by the $2^{\circ} \mathrm{C}$ isotherm in their sections, had a width of about $80 \mathrm{~km}$, extending vertically from $\sim 100$ to $\sim 500 \mathrm{~m}$. Peterson et al. [1982] gave a diameter of $100 \mathrm{~km}$ for the $4^{\circ} \mathrm{C}$ isotherm at $150 \mathrm{~m}$, and from their plots we obtain a width of $\sim 80 \mathrm{~km}$ for the $2^{\circ} \mathrm{C}$ isotherm at the same depth. The $2^{\circ} \mathrm{C}$ isotherm in our observations reaches from $\sim 100$ to $\sim 450 \mathrm{~m}$ and has its largest horizontal extension at $\sim 200$-m depth with $\sim 70 \mathrm{~km}$. Thus horizontal and vertical scales from these different observations are in good agreement. However, since we do not know whether our section cuts through the center of the eddy, the scales ob-
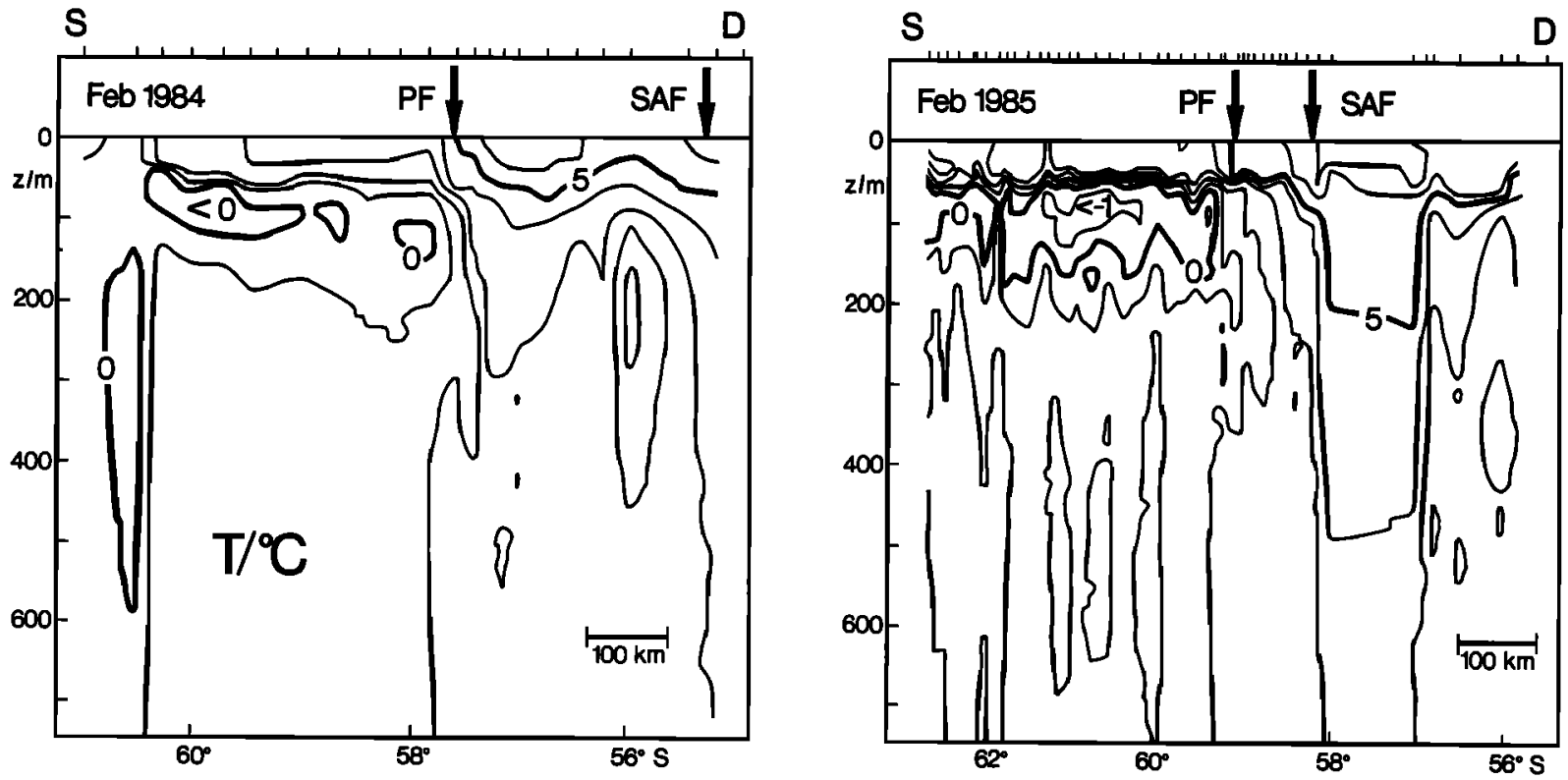

Fig. 5. Temperature sections S-D (see Figure 2) from XBT observations in February 1984 and February 1985. Tick marks indicate positions of XBT drops. Positions of fronts are given by arrows and front abbreviations. 


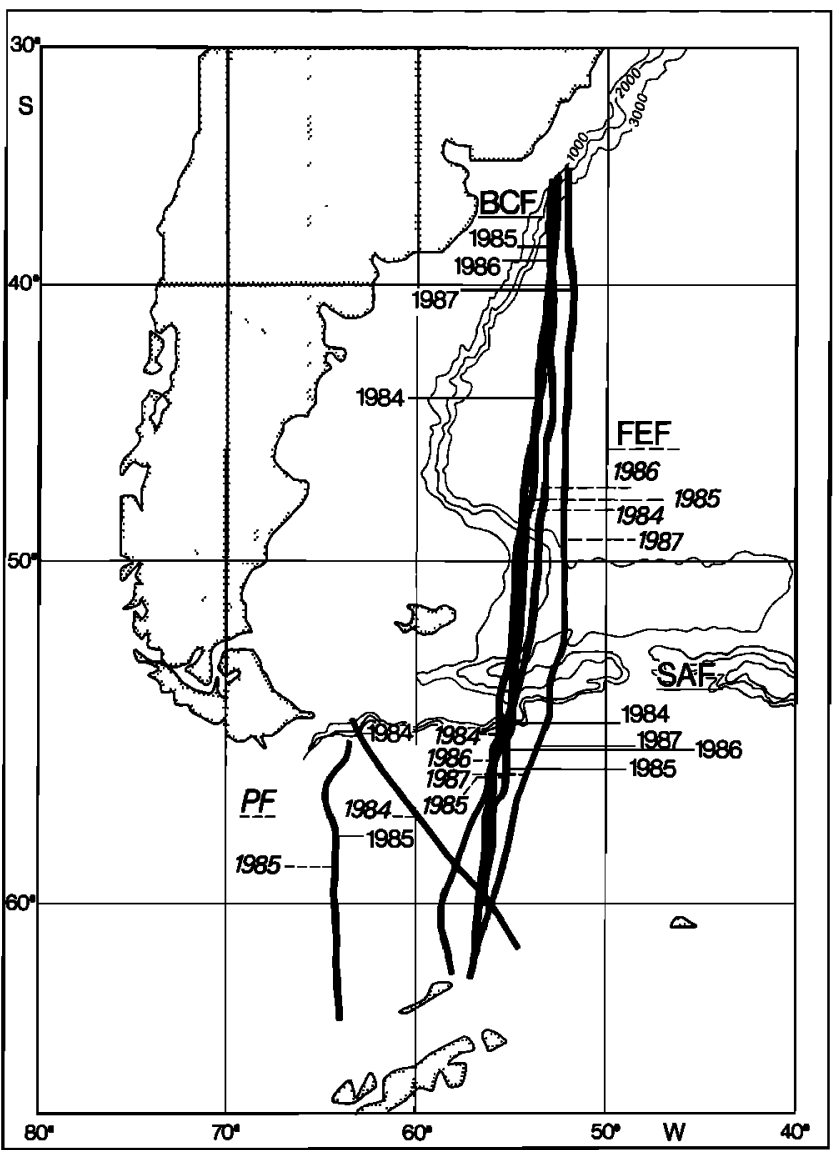

Fig. 6. Sections of this study with locations of fronts indicated for the different years.

served here are lower limits. The Polar and the Subantarctic fronts are separated by a larger distance than usual, $\sim 250 \mathrm{~km}$ in our observations.

\section{Conclusions}

Two thermal fronts are identified at the Brazil CurrentFalkland Current confluence zone. The Brazil Current Front restricts the warm subtropical water to the northern side, while the Falkland Escarpment Front indicates the boundary between the cold Falkland Current Water and the warmer near-surface water in the confluence zone. The Brazil Current Front displays a large variability in its location, while the Falkland Escarpment Front appears fixed to a narrow range

TABLE 2. Latitude (South) of Front Locations: Polar Front (PF), Subantarctic Front (SAF), Falkland Escarpment Front (FEF), and Brazil Current Front (BCF)

\begin{tabular}{lcccc}
\hline & \multicolumn{4}{c}{ Year } \\
\cline { 2 - 5 } Front & 1984 & 1985 & 1986 & 1987 \\
\hline & Sections Across & Southern Brazil-Antarctic Peninsula \\
BCF & $44^{\circ} 01^{\prime}$ & $38^{\circ} 26^{\prime}$ & $39^{\circ} 02^{\prime}$ & $40^{\circ} 09^{\prime}$ \\
FEF & $48^{\circ} 21^{\prime}$ & $47^{\circ} 57^{\prime}$ & $47^{\circ} 34^{\prime}$ & $49^{\circ} 18^{\prime}$ \\
SAF & $55^{\circ} 02^{\prime}$ & $56^{\circ} 21^{\prime}$ & $55^{\circ} 48^{\prime}$ & $55^{\circ} 45^{\prime}$ \\
PF & $55^{\circ} 18^{\prime}$ & $56^{\circ} 29^{\prime}$ & $56^{\circ} 04^{\prime}$ & $56^{\circ} 24^{\prime}$ \\
& & & & \\
SAF & Sections Across Drake Passage & \\
PF & $55^{\circ} 16^{\prime}$ & $58^{\circ} 15^{\prime}$ & \\
\hline
\end{tabular}

at the slope between the Falkland Plateau and the Argentine Abyssal Plain. The locations of the Polar and Subantarctic fronts on the long sections at similar longitudes do not vary much during the 4 years of observations. On a short section in the Drake Passage the Subantarctic Front appears displaced considerably to the north, in comparison with a typical position, owing to the existence of a cold core eddy with a ring diameter of $\sim 70 \mathrm{~km}$ in the Polar Frontal Zone.

Acknowledyments. The data were collected on the Brazilian research vessel Prof. $W$. Besnard, and the authors want to acknowledge the excellent work of the captain and the ship's crew and the technical staff on board. The analysis was conducted while the first author was a visiting scientist at the Institut für Meereskunde, Kiel University, Federal Republic of Germany. The authors have benefited from discussions with W. Nowlin, R. G. Peterson, and T. J. Müller. They also want to acknowledge the provision of the XBT probes by the Diretoria de Hidrografia e Navegacao, Brazil, the cruise support by Proantar, SECIRM, Brazil, and the assistance of the staff of the Marine Physics Department of the Institut für Meereskunde in Kiel, Federal Republic of Germany, in data processing. The third author received support from the Bundesminister für Forschung und Technologie (KF 2128).

\section{REFERENCES}

Baker, D. J., Jr., W. D. Nowlin, Jr., R. D. Pillsbury, and H. L. Bryden, Antarctic circumpolar current: Space and time fluctuations in the Drake Passage, Nature, 268, 696-699, 1977.

Botnikov, N. N., Geographical position of the Antarctic convergence zone in the Antarctic Ocean, Sov. Antarct. Exped. Inf. Bull., Engl. Transl., 4, 324-327, 11, 1963.

Brennecke, W., Die ozeanographischen Arbeiten der deutschen Antarktischen Expedition, 1911-1912. Arch. deutsch. Seewarte, XXXIX, Hamburg, 1921.

Bryden, H., Poleward heat flux and conversion of available potential energy in Drake Passage, J. Mar. Res., 37, 1-22, 1979.

Bryden, H., The Southern Ocean, in Eddies in Marine Science, edited by A. R. Robinson, pp. 265-277, Springer Verlag, New York, 1983.

Clifford, M. A., A descriptive study at the zonation at the Antarctic Circumpolar Current and its relation to wind stress and ice cover, M.S. thesis, Tex. A\&M Univ., College Station, Tex., 1983.

Deacon, G. E. R., The hydrology of the Southern Ocean, Discovery Rep., 15, 1-124, 1937.

Deacon, G. E. R., Physical and biological zonation in the Southern Ocean, Deep Sea Res., 29, 1-15, 1982.

Gordon, A. L., and C. L. Greengrove, Geostrophic circulation of the Brazil-Falkland confluence, Deep Sea Res., 33, 573-585, 1986.

Gordon, A. L., and E. J. Molinelli, Southern Ocean Atlas, 34 pp., Columbia University Press, New York, 1982.

Gordon, A. L., D. T. Georgi, and H. W. Taylor, Antarctic Polar Front Zone in the Western Scotia Sea-Summer 1975, J. Phys. Oceanogr., 7, 304-328, 1977.

Gordon, A. L., E. Molinelli, and T. Baker, Large-scale relative dynamic topography of the Southern Ocean, J. Geophys. Res., 83, 3023-3032, 1978.

Hofmann, E. E., and T. Whitworth III, A synoptic description of the flow at Drake Passage from year-long measurements, J. Geophys. Res., 90, 7177-7187, 1985.

Ikeda, Y., A. da Silveira Marcarenhas, Jr., P. Leão Cacciari, and L. Vianna Nonato, Um levantamento sinótico das Convergências Antártica e Subtropical, An. Acad. Bras. Ciênc., 58, Suppl., 111-116, 1986.

Joyce, T. M., and S. L. Patterson, Cyclonic ring formation at the polar front in the Drake Passage, Nature, 265, 131-133, 1977.

Joyce, T. M., S. L. Patterson, and R. C. Millard, Jr., Anatomy of a cyclonic ring in the Drake Passage, Deep Sea Res., 28A, 1265-1285, 1981.

Legeckis, R., Oceanic polar front in the Drake Passage-Satellite observations during 1976, Deep Sea Res., 24, 701-704, 1977.

Legeckis, R., and A. L. Gordon, Satellite observations of the Brazil and Falkland currents 1975 to 1976 and 1978, Deep Sea Res., 29, 375-401, 1982.

Mackintosh, N. A., The Antarctic Convergence and the distribution of surface temperature in Antarctic waters, Discovery Rep., 23, 177$212,1946$. 
Meinardus, W., Meteorologische Ergebnisse der Deutschen Südpolar-Expedition, 1901-1903, Disch. Südpolar Exped., III, Meteorol., I(1), 437-579, 1923.

Nowlin, W. D., Jr., and M. Clifford, The kinematic and thermohaline zonation of the Antarctic Circumpolar Current at Drake Passage, J. Mar. Res., 40, 481-507, 1982.

Nowlin, W. D., Jr., T. Whitworth III, and R. D. Pillsbury, Structure and transport of the Antarctic Circumpolar Current at Drake Passage from short-term measurements, J. Phys. Oceanogr., 7, 788-802, 1977.

Peterson, R. G., W. D. Nowlin, Jr., and T. Whitworth III, Generation and evolution of a cyclonic ring at Drake Passage in early 1979, $J$. Phys. Oceanogr., 12, 712-719, 1982.

Reıd, J. L., W. D. Nowlin, Jr., and W. C. Patzert, On the characteristics and circulation of the southwestern Atlantic Ocean, J. Phys. Oceanogr., 7, 62-90, 1977.

Roden, G. I., Thermohaline fronts and baroclinic flow in the Argentine Basin during the austral spring of 1984, J. Geophys. Res., 91, 5075-5093, 1986.
Schott, G., Die Grundlagen einer Weltkarte der Meeresströmungen, Ann. Hydrogr. Marit. Meteorol., 71, 281-282, 1943.

Sievers, H. A., and W. J. Emery, Variability of the Antarctic Polar Frontal Zone in the Drake Passage-Summer 1976/77, J. Geophys. Res., 83, 3010-3022, 1978.

World Climate Research Programme, General Circulation of the Southern Ocean: Status and Recommendations for Research, WCP-108, WMO/TD 86, World Meteorological Organization, Geneva, 1985.

Y. Ikeda, Instituto Oceanografico, Universidade de São Paulo, 05508 São Paulo, Brazil.

G. Siedler and M. Zwierz, Institut für Meereskunde, Düsternbrooker Weg 20, D-2300 Kiel 1, Federal Republic of Germany.

(Received July 31, 1988;

accepted August 15, 1988.) 